\title{
Determination the causative strain for hydatid cyst in Iraqi cattle by using ND1 gene
}

\author{
Mohammed J. Muhaidi'; Maysam N. Ahmed ${ }^{1}$ and Mohammed T. Dagash $^{2}$ \\ ${ }^{1}$ College of Veterinary Medicine, Al-Fallujah University, ${ }^{2}$ College of Medicine, Al- Anbar \\ University, Iraq. \\ E-mail: mjm20002014@gmail.com
}

Received: $24 / 10 / 2016$

Accepted: 27/12/2016

Summary

Hydatid Cysts were obtained from 15 cows from liver, lung, spleen, heart, and peritoneal cavity, between December 2014 and October 2015. Hydatid cysts (protoscoleces) were used for deoxyribonucleic acid extraction by using mechanical grinder. The purification of mtDNA was done by (promega kit, USA). The mitochondrial NADH dehydrogenase subunit 1 (NDI) genes were used as targets for polymerase chain reaction amplification, all hydatid cysts yielded amplification products. Polymerase chain reaction product for NADH1 800 basic pair. The polymerase chain reaction products were purified and partial sequences were generated. The sequences obtained were found to align with corresponding region for NDl gene in the Gene Bank nucleotide database confirming to genotype of sheep strain (G1) in Iraq, Phylogenetic analysis of partial sequence data from NDl genes for obtained Phylogenetic tree. G1 genotype was the most common taxon and was the actual source of infection of Iraqi's cattle. All of 15 strains were G1 genotype (sheep strain) based on the partial sequences of NADH dehydrogenase 1 (NDl).

Keywords: G1 strain hydatid cyst, ND1 gene, Cattle, Sequences.

Introduction

The larval stage caused Cystic echinococcosis of tape worm Echinococcus granulosus has a cosmopolitan distribution and is one of the most significant zoonosis all around the world (1 and 2). Cattle acquire infection by coming in contact with infected dogs harboring adult E. granulosus in their intestine resulting in excretion of eggs in the feces. Thus, one way that humans and other intermediate host can be infected is by swallowing ova that contaminate food, water or the environment generally (3). The extensive variation in E. granulosus may affect life cycle, host specificity, rate of development, pathology and consequently for design plus sensitivity to chemotherapeutic agents and development of vaccines against E. granulosus (4). In Iraq, CE constitutes one of the major endemic diseases and its seriousness in both humans and animals which has serious impacts on human or animal health (5-10). To date, 10 distinct genotypes (G1-G10 strain) have been described in the world based on nucleotide sequences analysis of the $(C O 1),(N D 1)$ genes and intra transcribed spacer 1 (ITS1); these genotypes have been associated with distinct, intermediate hosts: sheep, goats, pigs, cattle, horses, camels and cervides (11-16). The G1 genotype was also identified as the only genotype present in isolated from cattle, sheep and humans (17). A number of deoxyribonucleic acid (DNA) identification techniques have been employed to better identified Echinococcus species and genotypes from different intermediate and definitive hosts and in different geographical settings (18).

The aim of this study was to characterize the E. granulosus genotypes currently infecting cattle in Iraq, using polymerase chain reaction (PCR) and to estimate the genetic variability within the strains by sequencing the NADH dehydrogenase subunit 1 (ND1) genes.

Materials and Methods

The contents of 15 hydatid cysts were collected from different region of Iraq during 2014 to 2015 . Once cysts were washed several times with normal saline to decrease contamination with host tissue, and then they were extensively washed with $70 \%$ ethanol. According to (19), each cyst was separated into membrane and intra cystic fluid with protoscoleces. The cyst contents (fluid and protoscoleces) were aspirated aseptically by sterile syringes $(10 \mathrm{ml})$ into flask. Cysts were 
opened longitudinally incision and all the remaining protoscolex and fluid were aspirated and added to the flask content. The fluid was carefully and gradually decanted into sterile test tubes with spinning by centrifugation at $3000 \mathrm{rpm}$ for $10 \mathrm{~min}$. at room temperature to get of the protoscoleces to pellet. The germinal membrane was peeled away and washed several times with Hanks saline ( $\mathrm{pH} 2.0)$ containing $0.2 \%(\mathrm{w} / \mathrm{v})$ pepsin to free the remaining attached scoleces (20). The suspension was centrifugated at $3000 \mathrm{rpm}$ for 10 min., and the pellet of scoleces was collected. Protoscoleces were finally rinsed 34 times with sterile normal saline by repeated centrifugation followed by $70 \%$ ethanol, and stored in $70 \%$ ethanol at $4{ }^{\circ} \mathrm{C}$ temperature for further analysis. Pellet of protoscoleces were rinsed several times with sterile distilled water and Phosphate buffer saline (PBS) to remove ethanol prior to DNA extraction (21). DNA extraction was done by using Wizard (B)enomic DNA Purification Kit. (USA) and follow the instruction of manufacture (22). 20 ng of DNA from pellet of protoscoleces was used in all samples.

Twenty ng of DNA samples were analyzed by using the described methods with minor modifications (22) (Table, 1). The mitochondrial ND1 region was amplified by PCR using NDl F. and NDl R. primers (Table, 2) (17). The thermal conditions of the PCR ND1 reaction were as follows, denaturation for $4 \mathrm{~min}$. at $94^{\circ} \mathrm{C}$, followed by 35 cycles of 45 second at $94^{\circ} \mathrm{C}, 45$ second at $58^{\circ} \mathrm{C}$ and 45 second at $72^{\circ} \mathrm{C}$ and a final extension at $72^{\circ} \mathrm{C}$ for $7 \mathrm{~min}$.

Table, 1: PCR condition for ND1 gene.

\begin{tabular}{|l|c|}
\hline \multicolumn{1}{|c|}{ Criteria of cycle } & Conditions (temp/ time) \\
\hline Initial denaturation & $\mathbf{9 4}^{\circ} \mathrm{C} / 5$ min. \\
Amplification & $\mathbf{9 4}{ }^{\circ} \mathbf{C} / 45 \mathrm{~s} ; \mathbf{5 8}^{\circ} \mathrm{C} / 45 \mathrm{~s} ; \mathbf{7 2}^{\circ} \mathrm{C} / 45 \mathrm{~s}$ \\
Number of cycles & 35 \\
Final extension & $\mathbf{7 2}^{\circ} \mathrm{C} / 7$ min. \\
\hline
\end{tabular}

${ }_{\mathrm{mt}} \mathrm{DNA}$ sequencing and phylogenetic analysis fifteen amplicons were selected, and fragments of amplicons ND1 genes were amplified with primers published (17). DNA sequences were compared with partial NDI sequences from previous publications and
NCBI website (http://www.ncbi.nlm.nih.gov). Phylogenetic analysis of partial sequence data from $N D 1$ genes.

Table, 2: NADH dehydrogenase subunit 1 ND1 primer.

\begin{tabular}{|c|c|c|c|}
\hline \multicolumn{3}{|c|}{ Marker Size Code } & Sequence \\
\hline$N D I$ & $\begin{array}{c}800 \\
b p\end{array}$ & $\begin{array}{l}\text { ND1.F } \\
\text { ND1.R }\end{array}$ & $\begin{array}{l}\text { 5'-GTT TTT GGG TTA GTC TCT GG-3', } \\
\text { 5'-ATC ATA ACG AAC ACG TGG -3' }\end{array}$ \\
\hline
\end{tabular}

Results and Discussion

The target DNA was successfully amplified from 15 hydatid cyst isolates were prepared for PCR process by using specific primer. A PCR process to amplify DNA as the target gene was set up and performed on all 15 DNA samples. The agarose gel electrophoresis of PCR amplicon of ND1 gene (Fig.1).

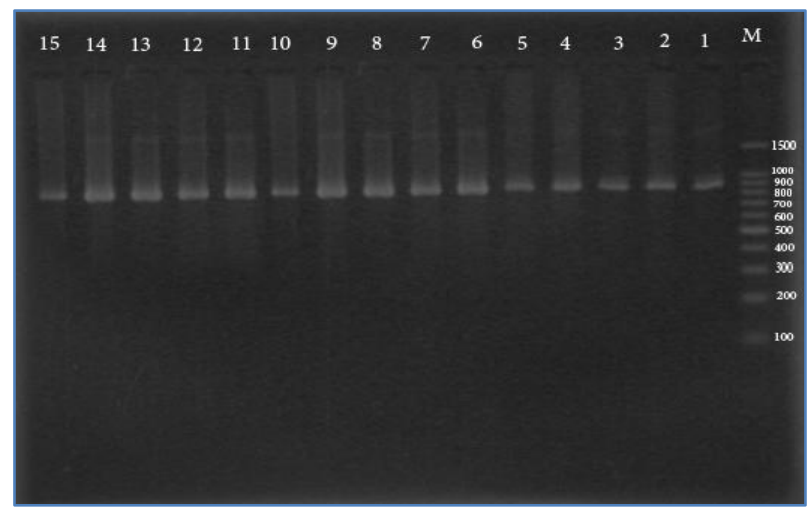

Figure, 1: Shows the agarose gel electrophoresis of PCR amplicon of $N D 1$ gene, using $2 \%$ agarose, $80 \mathrm{~V}, 70 \mathrm{Am}$ for 2 hrs., (lanes 1-15: E. granulosus isolates; M: 100 bp DNA ladder).

A partial region of the ND1 gene was amplified following a previously described protocol. To determine the genotypes of 15 isolates of cysts, NADH dehydrogenase subunit 1 gene was amplified by PCR, then sequenced and analyzed by alignments with reported reference sequences of G1 genotype of E. granulosus using Gene bank (Fig. 2). The sequence alignment was done by using Bioedit (DNA analysis program) and compared with previously reported references of E. granulosus genotypes. The results revealed $100 \%$ were identical with common sheep strain G1 genotype comparing with [ACCESSION KU925430] (23). 


\begin{tabular}{|c|c|c|c|}
\hline \multicolumn{2}{|c|}{$\begin{array}{c}\text { Score } \\
1410 \text { bits }(763)\end{array}$} & $\begin{array}{c}\text { Identities } \\
763 / 763(100 \%)\end{array}$ & $\begin{array}{l}\text { Strand } \\
\text { Plus/Plus }\end{array}$ \\
\hline Query & 20 & 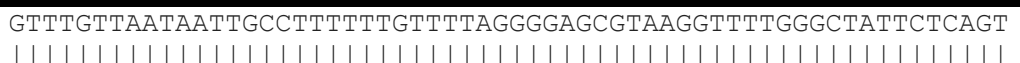 & 79 \\
\hline Sbjet & 4480 & GTTTGTTAATAATTGCCTTTTTTGTTTTAGGGGAGCGTAAGGTTTTGGGCTATTCTCAGT & 4539 \\
\hline Query & 80 & CTCGTAAGGGCCCTAACAAGGTTGGTGTAATTGGTTTGTTGCAGAGGTTTGCTGATCTAT & 139 \\
\hline Sbjet & 4540 & $\begin{array}{l}\text { | | | | | | | | | | | | | | | | | | | | | | | | | | | | | | | | | | | | | | | | | | | | | | | | | | | | | | | | | | | | | | | | | | | | } \\
\text { CTCGTAAGGGCCCTAACAAGGTTGGTGTAATTGGTTTGTTGCAGAGGTTTGCTGATCTAT }\end{array}$ & 4599 \\
\hline Query & 140 & TGAAGTTGGTAATTAAGTTTAAGTGTTTTTACTTCCAAAGTCGTAGGTATGTTGGTTTGT & 199 \\
\hline Sbjet & 4600 & $\begin{array}{l}\text { | | | | | | | | | | | | | | | | | | | | | | | | | | | | | | | | | | | | | | | | | | | | | | | | | | | | | | | | | | | | | | } \\
\text { TGAAGTTGGTAATTAAGTTTAAGTGTTTTTACTTCCAAAGTCGTAGGTATGTTGGTTTGT }\end{array}$ & 4659 \\
\hline Query & 200 & TTGGTGTTGTGTTATTAATGGCTTTGGTGATTGTTTATTCATTTATTTATGGTAGATATT & 259 \\
\hline Sbjet & 4660 & TTGGTGTTGTGTTATTAATGGCTTTGGTGATTGTTTATTCATTTATTTATGGTAGATATT & 4719 \\
\hline Query & 260 & $\begin{array}{l}\text { ATAGAgCTAGTTATAGAGGCCTCTCCGTGTTGTGGTTTTTGGCTGCCGCCAGAACATCTA } \\
|||||||||||||||||||||||||||||||||||||||||||||||||||||||||||||||||||||||||||||||||||||||| \mid\end{array}$ & 319 \\
\hline Sbjet & 4720 & ATAGAGCTAGTTATAGAGGCCTCTCCGTGTTGTGGTTTTTGGCTGCCGCCAGAACATCTA & 4779 \\
\hline Query & 320 & GGTATTCTTTGTTGTGTACTGGTTGGGGTGGTTACAACAATTATTCATTTTTAAGGTCGG & 379 \\
\hline Sbjet & 4780 & GGTATTCTTTGTTGTGTACTGGTTGGGGTGGTTACAACAATTATTCATTTTTAAGGTCGG & 4839 \\
\hline Query & 380 & TTCGATGTGCTTTTGGATCTGTTAGGTTTGAGGCTTGTTTTATGTGTGTGGTGATTTTTT & 439 \\
\hline Sbjet & 4840 & TTCGATGTGCTTTTGGATCTGTTAGGTTTGAGGCTTGTTTTATGTGTGTGGTGATTTTTT & 4899 \\
\hline Query & 440 & 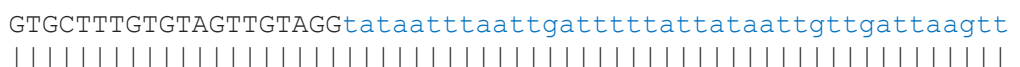 & 499 \\
\hline Sbjet & 4900 & GTGCTTTGTGTAGTTGTAGGTATAATTTAATTGATTTTTATTATAATTGTTGATTAAGTT & 4959 \\
\hline Query & 500 & tgttattatttccattaatttatgtgttatttttaatatgtATATTGTGTGAAACTAATC & 559 \\
\hline Sbjet & 4960 & $\begin{array}{l}\text { | | | | | | | | | | | | | | | | | | | | | | | | | | | | | | | | | | | | | | | | | | | | | | | | | | | | | | | | | | | | | | | | | | | | | | } \\
\text { TGTTATTATTTCCATTAATTTATGTGTTATTTTAATATGTATATTGTGTGAAACTAATC }\end{array}$ & 5019 \\
\hline Query & 560 & GTACGCCATTTGATTATGGAGAGGCTGAAAGAGAGTTGGTCAGTGGGTTTAAAGTTGAGT & 619 \\
\hline Sbjet & 5020 & $\begin{array}{l}\text { | | | | | | | | | | | | | | | | | | | | | | | | | | | | | | | | | | | | | | | | | | | | | | | | | | | | | | | | | | | | | | | | | } \\
\text { GTACGCCATTTGATTATGGAGAGGCTGAAAGAGAGTTGGTCAGTGGGTTTAAAGTTGAGT }\end{array}$ & 5079 \\
\hline Query & 620 & ATAGTGGTATTTATTTTACGTGTTTATTTGCTTGTGAGTATATTATTATATATGTGTTTT & 679 \\
\hline Sbjet & 5080 & $\begin{array}{l}\text { | | | | | | | | | | | | | | | | | | | | | | | | | | | | | | | | | | | | | | | | | | | | | | | | | | | | | | | | | | | | | | | | | } \\
\text { ATAGTGGTATTMTTTTACGTGTTTATTTGCTTGTGAGTATATTATTATATATGTGTTTT }\end{array}$ & 5139 \\
\hline Query & 680 & CATGGTTGGGAGTTGTGTTGATGTTTGGTGGCGGTTTTATCGGTATGTTGGTGTTAGTGT & 739 \\
\hline Sbjct & 5140 & 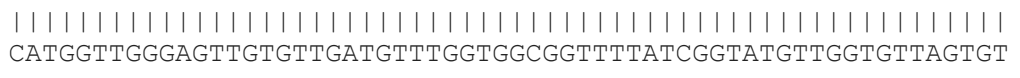 & 5199 \\
\hline Query & 740 & TTAATTTATTATTTTTTATGTGGGCTCGGGCGACATTACCACG & 782 \\
\hline Sbjct & 5200 & TTAATTTATTATTTTTTATGTGGGCTCGGGCGACATTACCACG & 5242 \\
\hline
\end{tabular}

Figure, 2: Alignment of NAD1 gene with reported reference sequences of G1 genotype of E. granulosus by using Gene bank.

The ND1 region was amplified by using a primer set designed for this study. The PCR amplification of NDl gene was successful in all isolates and generated products of approximately $800 \mathrm{bp}$, this result agreed with previous results done by $(17,24$ and 25$)$ where showed the size of NADH dehydrogenase subunit 1 (NDI) was 800 bp. Genotype G1 was the most common sheep infectious $E$. granulosus genotype in the world with a wide range of hosts (26). In these regions, dogs are often feed with livestock viscera that may be infected with the parasite (16).
This activity could be sufficient to propagate the current endemic state. From the results above, it can be indicated that the prominent circulation of the common sheep genotype (G1) was prevalent in hyper-endemic areas of Iraq. This result agreed with $(16,25$ and 26) possibly because it is the most common one also it is widespread among intermediate hosts (17 and 27). The identification of the genotypes of E. granulosus present in livestock and wild animals within regions endemic for E. granulosus is epidemiologically important. G1 genotype 
strains may also infect other intermediate host such as goats (28 and 29). A phylogenetic tree of the NDl genotypes was constructed using the maximum likelihood calculates with the Tamura-Nei distance, as the model of evolution (Fig. 3), (30).

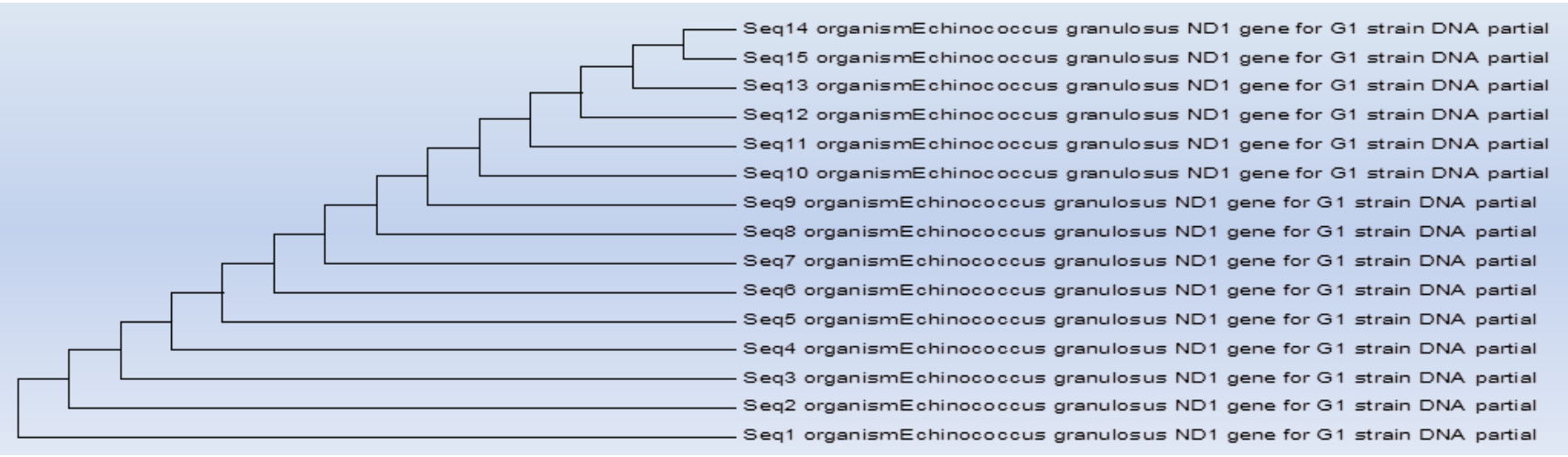

Figure, 3: Molecular phylogenetic analysis by maximum likelihood method

The evolutionary history was inferred by using the ceiling Likelihood method based on the Tamura-Nei model (30). The tree with the highest log likelihood (-980.0307) is shown. Elementary tree for the heuristic search was obtained automatically by applying NeighborJoin and BioNJ algorithms to a template of pairwise distances estimated using the Maximum Composite Likelihood approach, and then selecting the topology with officer log likelihood value. The tree is drawn to scale, with branch lengths measured in the number of replacement per site. The test involved 15 nucleotide sequences. Codon positions included were $1^{\text {st }}+2^{\text {nd }}+3^{\text {rd }}+$ Noncoding. All positions including gaps and absent data were eliminated. There were a total of 783 positions in the final dataset. Evolutionary analyses were conducted in MEGA7 (31). In conclusion the G1 genotype was the most common taxon and the actual source of infection of Iraqi's cattle. All of 15 strains were G1 genotype (sheep strain) based on the partial sequences of NADH dehydrogenase 1 (NDI).

\section{References}

1. Thompson, R. C. (2008). The taxonomy, phylogeny and transmission of Echinococcus. Exp Parasitol., 119:439-446.

2. Altintas, N.; Oztatlici, M.; Altintas, N. and Unver, A. (2013). Sakarya, A. Molecular Analysis of Cattle Isolates of Echinococcus granulosus in Manisa Province of Turkey. Kafkas Univ. Vet. Fak. Derg., 19(3):455459.

3. Fasihi, H. M.; Hobbs, R. P.; Adams, P. J.;
Mobedi, I.; Morgan-Ryan, U. M. and Thompson, R.C.A. (2002). Molecular and morphological characterization of Echinococcus granulosus of human and animal origin in Iran. Parasitolo., 125:367373.

4. McManus, D. P. and Thompson, R.C.A. (2003). Molecular epidemiology of cystic Echinococcosis. Parasitol., 127:37-51.

5. Al-jeboori, T. I.; (1976). Hydatid disease: A study of the records of the medical city hospital. J. Fact . Med. Baghdad. 18:65-75.

6. Mahmoud, S. S. (1980). Studies on hydatid disease in Mousl. M.Sc. Thesis, Collage of Medicine, University of Mosul.

7. Eckert, J.; Schantz, P. M.; Gasser, R. B.; Torgerson, P. R.; Bessonov, A. S. and Movsessian, S. O. (2001). Geographic distribution and prevalence. In: Eckert J, Gemmell MA, Meslin FX, Pawlowski ZS (eds) WHO/OIE Manual on Echinococcosis in Human and animals: A public health problem of global concern, Paris: World Organisation for Animal Health. Pp:100-142.

8. Dinkel, A.; Njorage, E. M.; Zimmermann, A.; Walz, M.; Zeyhle, E.; Elhamdi, I. E.; Mackenstedt, U. and Roming, T. (2004). A PCR systems for detection of species and genotypes of the Echinococcus granulosus complex, with reference to the epidemiological situation in eastern Africa. Int. J. Parasitol., 34(5):645-653.

9. Sarı̈zkan, S. and Yalçın, C. (2009). Estimating the production losses due to cystic echinococcosis in ruminants in Turkey. Vet. Parasitol., 163:330-334. 
10. Snabel, V.; Altınta, N.; D'Amelio, S.; Nakao, M.; Romig, T.; Yolasımaz, A.; Güne, K.; Türk, M.; Busi, M.; Hüttner, M. and Sevcova, D. (2009). Ito A, Dubinsky P. Cystic echinococcosis in Turkey: genetic variability and first record of the pig strain (G7) in the country. Parasitol. Res., 105:145154.

11. Breyer, I.; Georgieva, D.; Kurdova, R. and Gottstein, R. (2004). Echinococcus granulosus strain typing in Bulgaria: the G1 genotype is predominant in intermediate and definitive wild hosts. Parasitol. Res., 93:127130.

12. Romig, T.; Dinkel, A. and Mackenstedt, U. (2007). The present situation of Echinococcosis in Europe. Parasitol. Int., 55:187-191.

13. Varcasia, A.; Canu, S.; Kogkos, A.; Pipia, A. P.; Scala, A. Garippa, G. and Seimenis, A. (2007). Preliminary data on diffusion and molecular characterization of cystic Echinococcosis in small ruminants in Peloponnesus, Greece. Parasitol. Res., 101: 1135-1139.

14. Busi, M.; Snabel, V.; Vercasia, A.; Garippa, G.; Perrone, V.; De Liberato, C. and D'Amelio, S. (2007). Genetic variation within and between G1 and G3 genotypes of Echinococcus granulosus in Italy revealed by multilocus DNA sequencing. Vet. Parasitol., 150:75-83.

15. Nakao, M.; Mc Manus, D. P.; Schantz, P. M. and Craig, P. S. and Ito, A. (2007). A molecular phylogeny of the genus Echinococcus inferred from complete mitochondrial genomes. Parasitol., 134:713722.

16. Sanchez, E.; Caceres, O.; Naguira, C.; Garcia, D. and Patifio, G. (2010). Molecular characterization of Echinococcus granulosus from Peru by sequencing of the mitochondrial cytochrome $\mathrm{C}$ oxidase subunit 1 gene. Oswaldo Cruz, Rio de Janeiro. 105(6):221-232.

17. Sánchez, E.; Cáceres, O.; Náquir, A. C.; Miranda, E.; Samudio, F. and Fernandes, O. (2012). Echinococcus granulosus genotypes circulating in alpacas (Lama pacos) and pigs (Sus scrofa) from an endemic region in Peru. Mem Inst Oswaldo Cruz, Rio de Janeiro.;
107(2):275-278.

18. Eryıldı, C. and Şakru, N. (2012). Molecular Characterization of Human and Animal Isolates of Echinococcus granulosus in the Thrace Region,Turkey. Balkan Med J., 29: 261-267.

19. McManus, D. P. and Smyth, S. D. (1978). Differences in the chemical composition and carbondrate metabolisim of Echinococcus granulosus (horse and sheep strains) and E. multilocularis. Parasitol., 77:103-109.

20. Rishi, A. K. and McManus, D. (1987). Genomic cloning of human Echinococcus granulosus DNA: isolation of recombinant plasmids and their use as genetic markers in strain characterization. Parasitol., 94:369383.

21. Al-Azawiy, A. K. (2003). Immunization of experimental mice by DNA of protoscoleces of hydatid cyst: Immunological and histopathological studies. Ph.D. thesis, College of Veterinary Medicine, University of Baghdad. Iraq.

22. Miller, S. A.; Dykes, D. D. and Polesky, H. F. (1988). A simple salting out procedure for extracting DNA from human nucleated cells. Nucl. Acids Res., 16:1215.

23. Kinkar, L.; Laurimae, T.; Simsek, S. Balkaya, I. and Casulli, A. (2016). Highresolution phylogeography of zoonotic tapeworm Echinococcus granulosus sensu stricto genotype G1 with an emphasis on its distribution in Turkey, Italy and Spain. Parasitolo. In press, PUBMED 27572265.

24. Ergin, S.; Saribas, S. and Yuksel, P. (2010). Genotypic characterisation of Echinococcus granulosus isolated from human in Turkey. Afr. J. Microbiol. Res., 4(7):551-555.

25. Baraak, M. J. (2014). Molecular Study on Cystic Echinococcosis in Some Iraqi Patients. Ph.D. Thesis, College of Science, University of Baghdad. Iraq.

26. Craig, P. S.; Rogan, M. T. and CamposPonce, M. (2003). Echinococcosis: disease, detection and transmission. Parasitol., 127:5-20.

27. Rinaldi, L.; Maurelli, M. P.; Capuano, F.; Perugini, A. G. Veneziano, V. and Cringoli, S. (2008). Molecular update and cystic echinococcosis in cattle and water buffaloes of southern Italy, J. Blackwell verlag. 
Zoonosis, Pub. Heal. 55:119-123.

28. Eckert, J. and Thompson, R. C. (1997). Intraspesific variation of Echinococcus granulosus and related species with emphasis on their infectivity to humans. Acta. Trop. 64:19-34.

29. Mwambete, K. D.; Ponce-Gordo, F. and Cuesta-Bandera, C. (2004). Genetic identification and host range of the Spanish strains of Echinococcus granulosus. Acta. Trop., 91:87-93.
30. Tamura, K. and Nei, M. (1993). Estimation of the number of nucleotide sub- stitutions in the control region of the mitochondrial DNA in humans and chimpanzees. Mol. Biol. Evol., 10:512-526.

31. Kumar, S.; Stecher, G. and Tamura, K. (2016). MEGA7: Molecular Evolutionary Genetics Analysis version 7.0 for bigger datasets. Molecular Biology and Evolution. 33:1870-1874.

\section{تحديد السلائة المسببة للأكياس المائية في الأبقار العراقية باستعمال هين

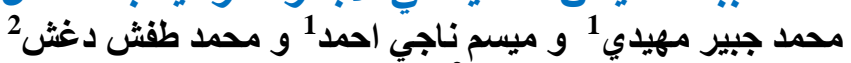

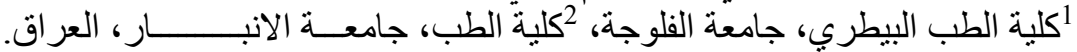

E-mail: mjm20002014@gmail.com

\section{الخلاصة}

إستُحصلت الأكياس المائية من 15 بقرة من الكبد، الرئة، الطحال، القلب والتجويف البريتوني ما بين كانون الأول 2014

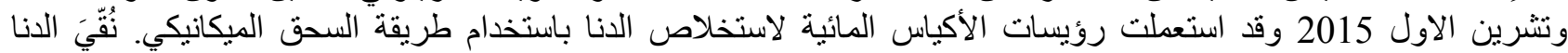

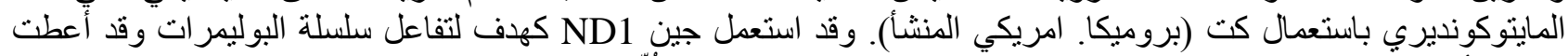

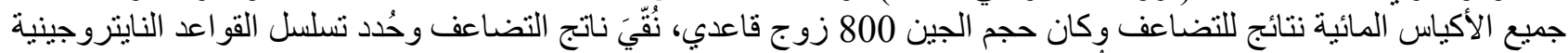

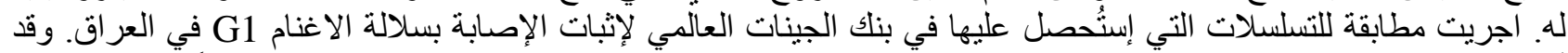

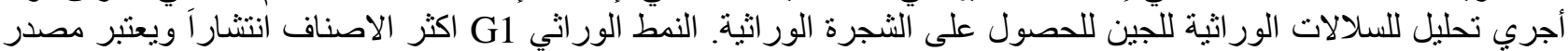

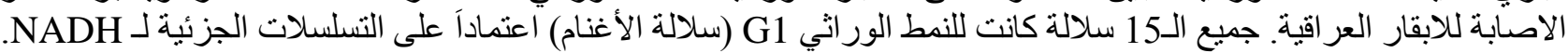

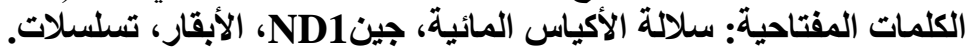

